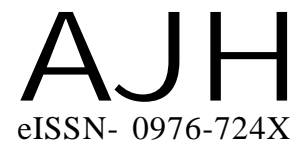

Received : 29.10.2017

Revised : 11.11.2017

Accepted : 18.11.2017

Members of the Research Forum

Associated Authors:

${ }^{1}$ Horticultural Research Station, (SKLTSHU), Dasnapur, ADILABAD (TELANGANA) INDIA
Author for correspondence : V. VIJAYA BHASKAR College of Horticulture, Dr. Y.S.R. Horticultural University, Anantharajupeta, KADAPA (A P.) INDIA
THEASIAN JOURNALOF HORTICULTURE

Volume 12 | Issue 2 | December, 2017 | 227-229

Visit us -www.researchjournal.co.in

RESEARCH PAPER

DOI : 10.15740/HAS/TAJH/12.2/227-229

\title{
Evaluation of gladiolus cultivars under the Northern Telangana zone
}

\section{VIJAYA BHASKAR AND P. SURYANARAYANA REDDY ${ }^{1}$}

ABSTRACT : An experiment was conducted to assess the performance of gladiolus cultivars at the Horticultural Research Station, Adilabad which comes under the Northern Telangana Zone. Among the 13 cultivars tested, 'Eurovision' has recorded significantly early flowering (55 days) when compared with all other cultivars. However, the plant height $(59.63 \mathrm{~cm})$, spike length and number of florets per spike (12) in the 'Eurovision' cultivar were significantly lowest when compared with all other cultivars. The cultivar 'Snow White' has recorded significantly longer duration of flowering (8.67days), whereas 'Meera', 'Friendship' and 'Shobha' were at par with 'Snow White'. 'American Beauty' has recorded significantly maximum vase life (9.00 days).

KEY WORDS : Gladiolus, Cultivar, Spike length, Flowering duration, Vase life

HOW TO CITE THIS ARTICLE : Bhaskar, V. Vijaya and Reddy, P. Suryanarayana (2017). Evaluation of gladiolus cultivars under the Northern Telangana zone. Asian J. Hort., 12(2) : 227-229, DOI : 10.15740/ HAS/TAJH/12.2/227-229. 